\title{
Eradicating cancer cells: struggle with a chameleon
}

\author{
Jiabo Di, Tjitske Duiveman-de Boer, Carl G. Figdor and Ruurd Torensma \\ * Department of Tumorimmunology, Radboud University Nijmegen Medical Centre, Nijmegen, The Netherlands
}

Correspondence to: Ruurd Torensma, email: r.torensma@ncmls.ru.nl

Received: February 24, 2011, Accepted: February 28, 2011, Published: February 28, 2011

Copyright: () Di et al. This is an open-access article distributed under the terms of the Creative Commons Attribution License, which permits unrestricted use, distribution, and reproduction in any medium, provided the original author and source are credited.

ABSTRACT:

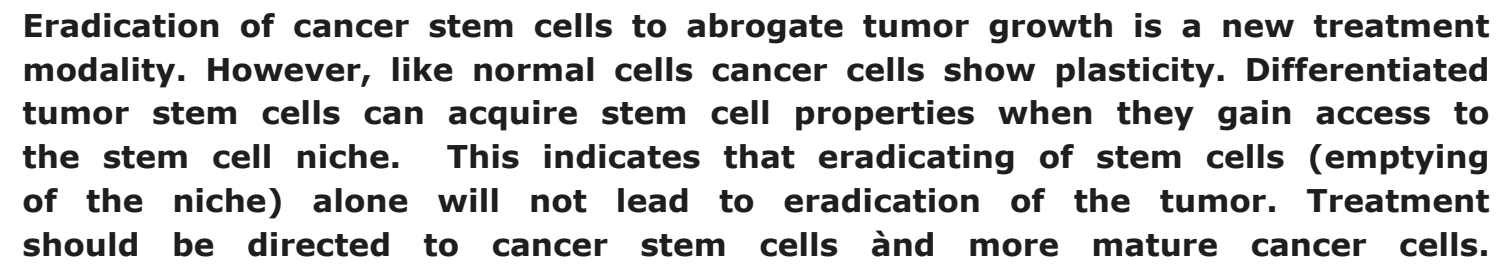

The discovery of cancer stem cells for solid tissues evoked an enormous research effort into this new avenue of treatment options [1]. Especially, the properties of cancer stem cells gained an enormous welcome because several in vivo findings could be explained. Cancer stem cells are resistant to irradiation and survive chemotherapeutic agents due to mechanisms very well known from normal stem cells. This in contrast to their mature offspring. Those stem cell features explain that- in a high percentage of patients- after killing the more mature tumor cells with these treatment modalities, the tumor will regrow. The first compounds that show specific killing of cancer stem cells are reported [2]. Such experiments suggest that the cancer stem cells could be killed given the right drugs are used [3]. Salinomycin one of the reported cancer stem cell drugs make stem cells that express multidrug transporters again vulnerable for chemotherapeutic drugs by blocking the drug expelling $\mathrm{ABC}$-transporter [4]. Expression of the ABCB5 transporter was reported to be confined to melanoma stem cells [5] and used as a target to eradicate cancer stem cells[6]. Also ALDH positive cells were shown to be enriched in tumor initiating cells[7].

However, for melanoma the cancer stem cell concept is challenged. Initially it was demonstrated using NOD/SCID mice that one in approximately one million cancer cells was able to evoke a tumor in those mice [810]. This frequency was challenged when other recipient mice were used and the tumor cells were implanted in matrigel [11-13]. This got recently a follow up with CD271 positive melanoma cells were the tumor initiating cells as deduced from an impressive number of different cancer cell lines cultured in vitro but also from cancer cells directly obtained from freshly excised tumors [14].
The ABCB5 positive fraction could be further enriched when the expresion of the VEGFR was taken into account [15]. However, this was challenged by other researchers [16].

One reason that increases tumor initiating cell frequency is the immune status of the mouse used for those experiments. Initially NOD/SCID mice that lack B- and T-lymphocytes were used. Later on more highly immunocompromised NOD/SCID interleukin-2 receptor gamma chain null (Il2ry(-/-) mice, which also lack NK cells were used. Such studies clearly demonstrate that heterogeneity exists in tumors: a population of cells that initiates tumors due to lack of immune surveillance whereas a less abundant population resists a better equipped immune system. Another reason for this difference in frequency of cancer initiating cells could rely in the plasticity of stem cells. The normal route for a stem cell is to differentiate from stem cell to mature tissue cells and is paved with several proliferation and maturation/differentiation steps. Several points in this differentiation are believed to be unidirectional, once taken no return is possible (lineage-commitment) [17]. Observed transdifferentiation was shown to be due to fusion of implanted stem cells with the diseased muscle or liver cells [18-20]. There are, however, data out that this is not as strict as propagated. Hematopoietic stem cells were able to dedifferentiate and become liver cells [21]. Knocking down JARID1B in slow cycling melanoma cells exhausted the tumor However, expression of JARID1B is dynamic since negative cells can become JARID1B positive [10]. Fibroblasts could transdifferentiate into cardiomyocytes [22]. Fibroblasts were even able to become blood cells without reprogramming into an iPS cell first [23] and endothelial cells could simply be converted 
into multipotent stem-like cells by transforming growth factor $\beta 2$ or bone morphogenetic protein 4 [24]. Also in the spermatogonial development more differentiated cells can go back to the stem cell state when the stem cell niche is emptied and the number of stem cells is decreased. Moreover, transient amplyfying cells in the gut require again stem cell properties when they contact paneth cells that supply them with Wnt and rescue the stem cell status. In this way the normal number of stem cells is recovered by differentiated stem cells that regain stem cell properties [25]. For melanoma such a mechanism could also be applicable. Dedifferentiation of more differentiated cells will level a shortage of stem cells. Just like a chameleon changes its color depending on the circumstances. If present, such plasticity would have major implications for therapeutic approaches that target only cancer stem cells. A combination therapy of destroying cancer stem cells as well as more mature progeny could wipe out the source of cancer cells. Moreover, as indicated above that more immune mice reject more tumorinitiating cells, enforcement of the immune system should aid in better survival of patients [26].

\section{REFERENCES}

1. Frank NY, Schatton T, Frank MH: The therapeutic promise of the cancer stem cell concept. J Clin Invest. 2010; 120:4150 .

2. Gupta PB, Onder TT, Jiang G, Tao K, Kuperwasser C, Weinberg RA, Lander ES: Identification of selective inhibitors of cancer stem cells by high-throughput screening. Cell. 2009; 138:645-59.

3. Hoey T, Yen WC, Axelrod F, Basi J, Donigian L, Dylla S, Fitch-Bruhns M, Lazetic S, Park IK, Sato A, Satyal S, Wang X, Clarke MF, Lewicki J, Gurney A: DLL4 blockade inhibits tumor growth and reduces tumor-initiating cell frequency. Cell Stem Cell. 2009; 5:168-77.

4. Fuchs D, Daniel V, Sadeghi M, Opelz G, Naujokat C: Salinomycin overcomes ABC transporter-mediated multidrug and apoptosis resistance in human leukemia stem cell-like KG-1a cells. Biochem Biophys Res Commun. 2010; 394:1098-104.

5. Frank NY, Margaryan A, Huang Y, Schatton T, WaagaGasser AM, Gasser M, Sayegh MH, Sadee W, Frank MH: ABCB5-mediated doxorubicin transport and chemoresistance in human malignant melanoma. Cancer Res. 2005; 65:4320-33.

6. Schatton T, Murphy GF, Frank NY, Yamaura K, WaagaGasser AM, Gasser M, Zhan Q, Jordan S, Duncan LM, Weishaupt C, Fuhlbrigge RC, Kupper TS, Sayegh MH, Frank MH: Identification of cells initiating human melanomas. Nature. 2008; 451:345-9.

7. Boonyaratanakornkit JB, Yue L, Strachan LR, Scalapino KJ, LeBoit PE, Lu Y, Leong SP, Smith JE, Ghadially R: Selection of tumorigenic melanoma cells using ALDH. J
Invest Dermatol. 2010; 130:2799-808.

8. Schatton T, Frank MH: Cancer stem cells and human malignant melanoma. Pigment Cell Melanoma Res. 2008; 21:39-55.

9. Zabierowski SE, Herlyn M: Learning the ABCs of melanoma-initiating cells. Cancer Cell. 2008; 13:185-7.

10. Roesch A, Fukunaga-Kalabis M, Schmidt EC, Zabierowski SE, Brafford PA, Vultur A, Basu D, Gimotty P, Vogt T, Herlyn M: A temporarily distinct subpopulation of slowcycling melanoma cells is required for continuous tumor growth. Cell. 2010; 141:583-94.

11. Quintana E, Shackleton M, Sabel MS, Fullen DR, Johnson TM, Morrison SJ: Efficient tumour formation by single human melanoma cells. Nature. 2008; 456:593-8.

12. Shackleton M, Quintana E: Progress in understanding melanoma propagation. Mol Oncol. 2010; 4:451-7.

13. Shackleton M, Quintana E, Fearon ER, Morrison SJ: Heterogeneity in cancer: cancer stem cells versus clonal evolution. Cell. 2009; 138:822-9.

14. Boiko AD, Razorenova OV, van de Rijn M, Swetter SM, Johnson DL, Ly DP, Butler PD, Yang GP, Joshua B, Kaplan MJ, Longaker MT, Weissman IL: Human melanomainitiating cells express neural crest nerve growth factor receptor CD271. Nature. 2010; 466:133-7.

15. Frank NY, Schatton T, Kim S, Zhan Q, Wilson BJ, Ma J, Saab KR, Osherov V, Widlund HR, Gasser M, WaagaGasser AM, Kupper TS, Murphy GF, Frank MH: VEGFR-1 expressed by malignant melanoma initiating cells is required for tumor growth. Cancer Research. OnlineFirst January 6, 2011; doi: 10.1158/0008-5472.CAN-10-1660.

16. Quintana E, Shackleton M, Foster HR, Fullen DR, Sabel MS, Johnson TM, Morrison SJ: Phenotypic Heterogeneity among Tumorigenic Melanoma Cells from Patients that Is Reversible and Not Hierarchically Organized. Cancer Cell. 2010; 18:510-23.

17. Wagers AJ, Weissman IL: Plasticity of adult stem cells. Cell. 2004; 116:639-48.

18. Camargo FD, Chambers SM, Goodell MA: Stem cell plasticity: from transdifferentiation to macrophage fusion. Cell Prolif. 2004; 37:55-65.

19. Camargo FD, Finegold M, Goodell MA: Hematopoietic myelomonocytic cells are the major source of hepatocyte fusion partners. J Clin Invest. 2004; 113:1266-70.

20. Vassilopoulos G, Wang PR, Russell DW: Transplanted bone marrow regenerates liver by cell fusion. Nature. 2003; 422:901-4.

21. Jang YY, Collector MI, Baylin SB, Diehl AM, Sharkis SJ: Hematopoietic stem cells convert into liver cells within days without fusion. Nat Cell Biol. 2004; 6:532-9.

22. Ieda M, Fu JD, Delgado-Olguin P, Vedantham V, Hayashi Y, Bruneau BG, Srivastava D: Direct reprogramming of fibroblasts into functional cardiomyocytes by defined factors. Cell. 2010; 142:375-86.

23. Szabo E, Rampalli S, Risueno RM, Schnerch A, Mitchell 
R, Fiebig-Comyn A, Levadoux-Martin M, Bhatia M: Direct conversion of human fibroblasts to multilineage blood progenitors. Nature. 2010; 468:521-6.

24. Medici D, Shore EM, Lounev VY, Kaplan FS, Kalluri R, Olsen BR: Conversion of vascular endothelial cells into multipotent stem-like cells. Nat Med. 2010; 16:1400-6.

25. Morimoto H, Kanatsu-Shinohara M, Takashima S, Chuma S, Nakatsuji N, Takehashi M, Shinohara T: Phenotypic plasticity of mouse spermatogonial stem cells. PLoS ONE. 2009; 4:e7909.

26. de Vries IJ, Lesterhuis WJ, Scharenborg NM, Engelen LP, Ruiter DJ, Gerritsen MJ, Croockewit S, Britten CM, Torensma R, Adema GJ, Figdor CG, Punt CJ: Maturation of dendritic cells is a prerequisite for inducing immune responses in advanced melanoma patients. Clin Cancer Res. 2003; 9:5091-100. 